UDK 630*411.16:595.787 Lymantria

Original scientific paper

\title{
TESTING OF SOIL DISTRIBUTION, VIABILITY, AND INFECTIVITY OF AZYGOSPORES OF THE ENTOMOPATHOGENIC FUNGUS Entomophaga maimaiga
}

\author{
Mara TABAKOVIĆ-TOŠIĆ ${ }^{l}$, Sanja JOVANOVIĆ ${ }^{l}$, Marija MILOSAVLJEVIĆ ${ }^{l}$
}

\begin{abstract}
Entomophaga maimaiga is one of the best-known gypsy moth pathogens with increasing importance in the biological control aimed at reducing the population of this defoliator. The territory of the Republic of Serbia is a very favorable gypsy moth habitat, and the problems caused by its larvae during the periods of outbreaks are so great that they can lead to forest defoliation and forest health deterioration.

In the Republic of Serbia, E. maimaiga was first recorded in 2011 (as a new species in the microflora of Serbia) during the gypsy moth outbreak (2009-2014), which was the last to date. In 2011, numerous dead caterpillars were found on and around trees in oak and beech stands of the Belgrade and Valjevo regions in Serbia. Subsequent laboratory analyses revealed that they contained azygospores and conidia of this fungus. The assisted introduction of E. maimaiga was carried out in Compartments 28 and 30 of the FMU Avala on Mt. Avala in 2011. It led to an epizootic in the following year and stopped the outbreak of the gypsy moth in the area.

Since it has been seven years since the outbreak, we tested the viability and infectivity of E. maimaiga azygospores obtained from the soil samples from Avala Mountain where its assisted introduction was carried out. We used larvae from the laboratory gypsy moth population and applied the bioassay method. The results show that azygospores are present in the given soil samples, they are viable and their infectivity is conserved. It can be concluded that in the case of an outbreak of gypsy moth populations in the future, they will exhibit their entomopathogenic effect.
\end{abstract}

Keywords: Avala, soil, Entomophaga maimaiga, azygospores, infectivity

\footnotetext{
${ }^{1}$ Institute of Forestry, 3 Kneza Višeslava, Belgrade, Serbia
} 


\section{ISPITIVANJE PRISUSTVA U ZEMLJIŠTU, VIJABILNOSTI I INFEKTIVNOG POTENCIJALA AZIGOSPORA ENTOMOPATOGENE GLJIVE Entomophaga maimaiga}

Izvod: Entomophaga maimaiga je jedan od najpoznatijih patogena gubara $i$ zauzima sve veći značaj u biološkim merama borbe, koje imaju za cilj smanjenje brojnosti populacija ovog defolijatora. Teritorija Republike Srbije je veoma povoljno stanište za gubara, te su i problemi koje njegove larve izazivaju u periodima gradacije veliki, dovodeći do golobrsta i slabljenja zdravstvenog stanja šuma.

U Republici Srbiji E. maimaiga je prvi put uočena 2011. godine (nova vrsta $u$ mikoflori Srbije), kada je bila u toku gradacija gubara (2009-2014), poslednja do danas. U Srbiji, u hrastovim $i$ bukovim sastojinama u regionu Beograda $i$ Valjeva, 2011. godine nađene su brojne mrtve gusenice gubara na stablima $i$ oko njh, za koje se kasnije, laboratorijskim analizama, utvrdilo da sadrže azigospore $i$ konidije ove gljive. Potpomognuta introdukcija E. maimaiga vršena je 2011. godine na planini Avala, u Gazdinskoj jedinici Avala, odeljenjima 28 i 30, i već naredne je uzrokovala epizootiju, te dovela do sloma gradacije gubara na tom prostoru.

$S$ obzirom da je od tada prošlo 7 godina, metodom bioeseja ispitivali smo vijabilnost $i$ infektivni potencijal azigospora E. maimaiga iz uzoraka zemljišta sa planine Avala, gde je vršena njena potpomognuta introdukcija, na larvama iz laboratorijske populacije gubara. Rezultati su pokazali da su azigospore prisutne u datim uzorcima zemljišta, kao $i$ da su vijabilne $i$ da je njihov infektivni potencijal očuvan, te se može zaključiti da će u slučaju naredne gradacije populacija gubara, one ispoljiti entomopatogeni efekat. potencijal

Ključne reči: Avala, zemljište, Entomophaga maimaiga, azigospore, infektivni

\section{INTRODUCTION}

Entomophaga maimaiga Hamber, Shimauzu \& Soper (Entomophtorales: Entomophtoraceae) is a natural, obligate pathogen of the best-known forest pest gypsy moth Lymantria dispar L. (Lepidoptera: Erebidae). Gypsy moth is a significant defoliator of deciduous forests in the temperate zone of the northern hemisphere. Its populations are characterized by a cyclical occurrence, with alternating periods of latency and outbreak. The damage caused to forests by gypsy moth larvae in outbreaks is considerable and has far-reaching consequences. They deteriorate the overall forest health, weaken trees and make them susceptible to infections caused by other organisms. This problem is particularly pronounced in the Republic of Serbia because it has the considerable area covered by deciduous forests and the climate is suitable for the development of the gypsy moth, with the climate change trends indicating that it will be so in the future (Stojanovic et al., 2016). Therefore, it is of great importance for the conservation of forest ecosystems that E. maimaiga has been discovered and recognized as an exceptional biological agent of high host specificity (Hayek, 1999). It is self-sustaining and capable of regulating the abundance of gypsy moth populations, and therefore economically viable in the biological fight against gypsy moth (Belme, 1995). 
E. maimaiga belongs to the Entomophaga aulicae species complex, within which it has been identified as a separate species based on the differences in isozymes, its ability to infect L. dispar, as well as the results of analyses that compared the restriction fragment length polymorphism (Walsh et al., 1990).

Two different types of asexual spores are produced during the life cycle of E. maimaiga: conidia and azygospores. Azygospores are multinucleate, light yellow structures containing lipid drops. They are formed in late spring, or early summer in the cadavers of gypsy moth caterpillars. They are round and average $32.1 \mu \mathrm{m}$ in diameter (Hajek, 1999), surrounded by a thick, double-cell wall since they are overwintering organisms. As caterpillar cadavers can remain attached to the tree or fall off to the ground, these spores can be found in the soil, litter, and tree bark. Research conducted by Hajek et al. (1998) has shown that the largest number of azygospores can be found around the stem base in the radius of $10 \mathrm{~cm}$ and then their density decreases. The research has also confirmed that they are most abundant in the organic soil layer, while their number decreases with increasing depth. At the beginning of spring, azygospores germinate and infect the host, proliferating in its hemolymph. They disturb the normal cellular metabolism and cause the nutrient depletion of the organism, which ultimately leads to the death of gypsy moths. Such a course of events is also referred to as primary transmission and is thought to be the cause of death of larvae of earlier instars. It has been observed that azygospores can persist in the soil for up to 12 years (Hajek et al., 2000; Hajek et al., 2004), allowing the fungus to survive at times when the host is absent or inactive.

After the death of the host, hyphae release conidia that are capable of infection, and their hosts are larvae of later developmental stages. This type of infection is referred to as secondary transmission and is very important in amplifying the primary E. maimaiga attack on the gypsy moth. It serves to spread infection in the larval population in the spring, thus significantly increasing the overall positive effect in controlling the pest abundance. Besides the presence of the host, successful infection requires adequate environmental conditions, among which moisture is particularly important. The availability of water in a liquid or gaseous state is essential for the germination of azygospores, therefore it can be concluded that high rainfall at the beginning of the annual cycle of the moth and the fungus is crucial.

E. maimaiga was introduced as a biocontrol agent of the gypsy moth into the United States in the period from 1910 to 1911. (Speare, Colley, 1912) and Bulgaria in 1999 (Pilarska et al., 2000) and from there it has been constantly spreading across North America and Europe.

In the Republic of Serbia, E. maimaiga was first recorded in 2011 (Tabaković-Tošić et al., 2012), during the gypsy moth outbreak (2009 - 2014), which was the last to date. Numerous dead gypsy moth caterpillars were found on and around trees in oak and beech stands of the Belgrade and Valjevo regions in Serbia in 2011. Subsequent laboratory analyses revealed that they contained azygospores and conidia of this fungus. These images could also be seen in 13 regions across Serbia in the coming years (Tabaković-Tošić, 2014a; TabakovićTošić, 2015). 
The assisted introduction of E. maimaiga was carried out in Compartments 28 and 30 of FMU Avala on Mt. Avala in 2011 (Tabaković-Tošić, 2014b). It led to an epizootic in the following year and stopped the outbreak of the gypsy moths in the area. As it has been seven years since the outbreak, we tested the viability and infectivity of E. maimaiga azygospores obtained from the soil samples from Avala Mountain where its assisted introduction was carried out. We used larvae from the laboratory gypsy moth population.

\section{MATERIAL AND METHODS}

\subsection{Material}

Experimental $L$. dispar larvae were obtained from egg masses of their natural environment in central Serbia. Egg masses were collected during September 2018 and kept in the refrigerator at $4^{\circ} \mathrm{C}$ before they were used. The eggs were placed to hatch in an air-conditioning chamber at a temperature of $20^{\circ} \mathrm{C}$. After hatching, the caterpillars were also grown under constant ambient conditions, at a temperature of $22^{\circ} \mathrm{C}$. The light regime was in the ratio of 16 to 8 hours (light: dark). Gypsy moth larvae were fed daily with specially-formulated artificial food prepared from wheat germs, casein, Salt mixture Wesson, sorbic acid, methyl parabens, appropriate vitamins, agar, and distilled water, according to a given recipe. Third-instar larvae were used in the experiment.

Two types of soil were used in the experiments. Commercial soil (humus) was used in the experiments representing positive and negative controls. The second type included soil samples collected in late February 2019 in oak and beech forests of FE Belgrade, Avala Forest Administration, FMU Avala where E. maimaiga was introduced in two locations in 2011 - compartments 28 and 30. Five trees were selected in each location. Soil samples were augured from the base of the trees at a depth of $1-5 \mathrm{~cm}$, with prior clearing of the litter as close to the root shoot as possible. The sample included the organic layer. The drill was washed and sterilized with $95 \%$ ethanol every time before the auguring. The collected soil samples were stored in the laboratory under natural light conditions and at a temperature of $15^{\circ} \mathrm{C}$, with minor variations.

\subsection{Methods}

The research applied the bioassay method. Three experiments were performed. They included 3 experimental units in 5 replications.

In each experiment, 5 third-instar gypsy moth caterpillars were placed in each of 15 plastic boxes measuring $10 \times 10 \mathrm{~cm}$ and containing about $100 \mathrm{~cm}^{3}$ of soil. In the first 10 days of the experiment, the soil was moistened with $10 \mathrm{ml}$ of distilled water per day.

The experiments differed in the initial steps of soil preparation.

The first experiment was a negative control and contained gypsy moth larvae exposed to sterilized soil. The purchased soil (humus) had been sterilized at $180^{\circ} \mathrm{C}$ for 2 hours before it was used. The purpose of this experiment was to prove that the larvae did not contain E. maimaiga spores. 
In the second experiment, we used the soil taken from Mt. Avala. The samples from compartment 28 were mixed and shredded and then placed in plastic containers. The same procedure was applied to compartment 30 soil samples.

The third experiment was a positive control. The purchased soil (humus) was sterilized at $180^{\circ} \mathrm{C}$ for 2 hours. After the sterilization, E. maimaiga azygospores originating from homogenized cadavers of infected gypsy moth caterpillars (20 caterpillar cadavers per $1500 \mathrm{~cm}^{3}$ of soil) were added. The caterpillars were collected in nature and the microscopic analysis proved them to be abundant in E. maimaiga azygospores. This experiment aimed to determine the susceptibility of gypsy moth larvae to E. maimaiga infection.

The gypsy moth larvae used in the experiments were grown under ambient conditions identical to those before the experiments were set up.

The development of larvae was monitored daily. Once a dead individual was observed, it was placed in a separate sterile petri dish with moist filter paper and stored for 7 days in an air-conditioning chamber under identical ambient conditions to allow the development of azygospores. Afterwards, the Petri dishes were moved to the refrigerator, where they stayed for further 5 months at $4^{\circ} \mathrm{C}$. At the end of this period, all cadavers were subjected to microscopic analysis. A BTC light microscope that magnifies up to 125 times was used. The presence of $E$. maimaiga infection was marked positive if azygospores were observed in the bodies of dead larvae. The species were identified based on the size, shape, and structural characteristics of different fungal life forms. For this purpose, we used a Motic BA410E light microscope equipped with a 10.0 Mp Moticam digital camera. The digital photographs were processed and analyzed using Motic Images Plus 2.0 digital microscope image processing software.

\section{RESULTS AND DISCUSSION}

The results of this study reveal the viability and infectivity of $E$. maimaiga azygospores on Mt. Avala, 8 years after its onset and 7 years after the epizootic in this area.

The negative control, in which $L$. dispar caterpillars were exposed to sterilized soil, had a mortality rate of $4 \%$. Microscopic analysis of dead larvae showed the absence of any E. maimaiga life form. The cause of their death is unknown.

The results of the examination of the presence of E. maimaiga azygospores in $L$. dispar larvae exposed to soil samples from the experimental site of compartment 28 on Mt. Avala are shown in Table 1 (A). It can be seen from the results that the caterpillar mortality amounted to $90.66 \%$. Azygospores of $E$. maimaiga were found in $36 \%$ of the total number of larvae in the experiment. Regarding the total number of dead caterpillars, azygospores were found in $39.7 \%$ of them. 
Table 1. The presence of E. maimaiga azygospores in the dead larvae of $L$. dispar exposed to compartments $28(A)$ and $30(B)$ soil samples, as well as in the positive

\begin{tabular}{|c|c|c|c|c|c|c|c|c|c|c|c|c|c|c|c|c|}
\hline \multirow{4}{*}{$\begin{array}{l}\text { Experimental } \\
\text { unit }\end{array}$} & & & & & & & & & & & & & & & & \\
\hline & \multirow{4}{*}{$\begin{array}{c}\text { Dead larva } \\
\text { sequence number }\end{array}$} & \multicolumn{15}{|c|}{ E. maimaiga azygospores } \\
\hline & & \multicolumn{15}{|c|}{ Replication } \\
\hline & & \multicolumn{3}{|c|}{$\mathrm{I}$} & \multicolumn{3}{|c|}{ II } & \multicolumn{3}{|c|}{ III } & \multicolumn{3}{|c|}{ IV } & \multicolumn{3}{|c|}{$\mathrm{V}$} \\
\hline & & A & $\mathrm{B}$ & $\mathrm{C}$ & A & B & $\mathrm{C}$ & A & B & $\mathrm{C}$ & A & $\mathrm{B}$ & $\mathrm{C}$ & A & B & $\mathrm{C}$ \\
\hline \multirow{5}{*}{1} & 1 & - & + & - & - & - & + & - & - & - & - & - & - & + & + & - \\
\hline & 2 & - & - & - & + & I & + & + & - & + & + & - & - & + & - & - \\
\hline & 3 & + & - & - & - & I & - & I & - & - & + & - & - & + & - & - \\
\hline & 4 & + & - & - & + & - & + & - & - & - & - & - & - & - & - & - \\
\hline & 5 & + & - & - & - & - & + & - & - & - & + & - & - & - & - & - \\
\hline \multirow{5}{*}{2} & 1 & - & - & - & - & - & + & - & - & - & - & - & - & - & + & - \\
\hline & 2 & + & - & - & - & - & - & 1 & - & + & - & - & - & + & + & - \\
\hline & 3 & 1 & - & - & + & - & - & + & - & + & - & + & - & + & - & - \\
\hline & 4 & - & - & - & - & - & - & - & - & - & - & - & - & + & - & - \\
\hline & 5 & - & - & - & - & + & + & - & - & + & - & - & - & - & - & 1 \\
\hline \multirow{5}{*}{3} & 1 & - & - & - & - & - & - & - & 1 & - & - & - & - & - & - & 1 \\
\hline & 2 & + & - & - & + & - & - & + & 1 & - & - & - & - & - & - & 1 \\
\hline & 3 & - & 1 & - & + & - & - & + & 1 & - & 1 & - & - & 1 & 1 & 1 \\
\hline & 4 & 1 & 1 & - & - & - & - & + & 1 & + & + & 1 & - & - & 1 & 1 \\
\hline & 5 & 1 & 1 & - & + & 1 & - & - & 1 & - & - & 1 & - & + & 1 & 1 \\
\hline
\end{tabular}

Legend:

(/) a gypsy moth caterpillar that successfully completed the larval stage and resumed development

(-) A dead gypsy moth caterpillar in which the presence of azygospores was not detected

(+) A dead gypsy moth caterpillar in which the presence of azygospores was detected

The results of testing the presence of E. maimaiga azygospores in L. dispar larvae exposed to soil samples from the experimental site of compartment 30 are shown in Table 1(B). The mortality of caterpillars amounted to $78.66 \%$. Azygospores of E. maimaiga were found in $8 \%$ of the total number of larvae in the experiment. Of the total number of dead caterpillars, $10.16 \%$ had the azygospores of the fungus.

The positive control in which the gypsy moth larvae were exposed to sterilized soil and E. maimaiga azygospores derived from homogenized cadavers of infected caterpillars produced the results presented in Table 1(C). The caterpillars had a mortality rate of $92 \%$. Azygospores of E. maimaiga were recorded in $14.66 \%$ of the total number of larvae in the experiment. Regarding the total number of dead caterpillars, azygospores were found in $15.94 \%$ of them.

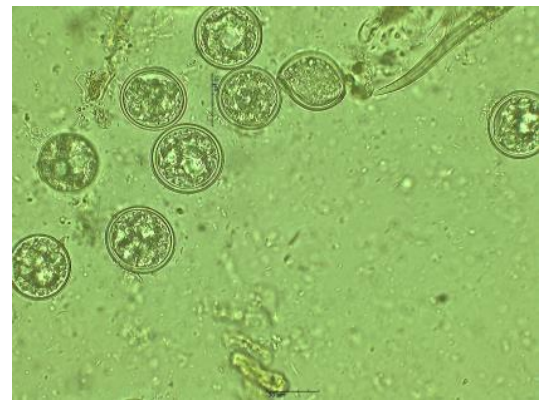

Figure 1. E. maimaiga azygospores (40x magnification)

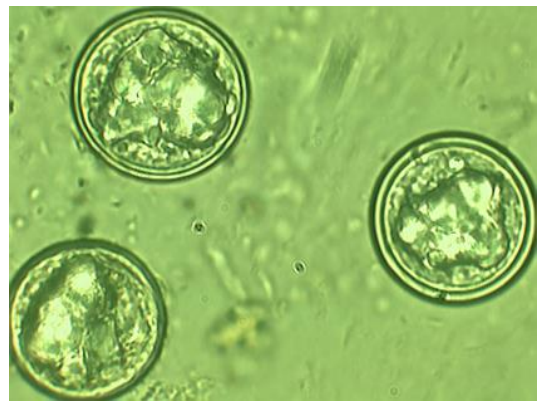

Figure 2. Mature azigospores of E. maimaiga with lipid drops (100x magnification) 
Confirmation that the observed azygospores belong to the E. maimaiga species was obtained by observing the spore morphology (Figure 1). They are round, about $30 \mu \mathrm{m}$ in diameter, with a clearly defined cell wall, about $2 \mu \mathrm{m}$ thick. Several lipid drops were observed internally (Figure 2).

The experiments performed clearly proved the presence of E. maimaiga azygospores in the soil taken from compartments 28 and 30. Their properties, namely the viability and infectivity, were examined simultaneously due to the nature of the method used. Gypsy moth larvae could be infected only with viable azygospores.

The results of the experiments in which gypsy moth larvae were exposed to soil samples obtained from compartments 28 and 30 indicate a high mortality rate in both compartments $(90.66 \%$ and $78.66 \%$, respectively), but the mortality caused by the fungus was lower (39.7\% and $10.16 \%$ respectively). The cause of death of the gypsy moth larvae which did not detect the presence of E. maimaiga azygospores during microscopy is unknown. No life forms of other pathogenic organisms were observed. High caterpillar mortality was expected, but it was expected to be caused by E. maimaiga infection. There are several explanations for the low percentage of the infection with the fungal larvae. One option is that $E$. maimaiga is the cause of caterpillar mortality, but that there was not enough time to form azygospores.

It is also possible that the concentration of E. maimaiga spores was very low at the examined sites. Another possibility is that we could not provide laboratory conditions required for the gypsy moth infection to occur. Namely, the infection in nature requires high air humidity in the form of water droplets (Hajek et al., 1990; Weseloh and Andreadis, 1992) over a period of two days, which is difficult to provide under laboratory conditions. In this case, the viable spores that were present in the soil samples, but did not cause infection, could not be detected using this method. It is also possible that the azygospores had reduced infectivity.

If we compare the results of the experiments that used the soil samples from Mt. Avala, it can be observed that compartment 28 had a higher rate of larval mortality $(90.66 \%)$ than compartment 30 , as well as a higher rate of mortality caused by E. maimaiga (39.7\%). Such results may have been caused by the lower concentration of spores in the soil samples from compartment 30 or the environmental conditions necessary for the infection of gypsy moth larvae were not fully ensured.

\section{CONCLUSIONS}

Despite the small number of dead L. dispar caterpillars with the presence of fungal azygospores, which would prove them to be the cause of their death, they provide clear evidence that the viability and infectivity of E. maimaiga spores have been preserved since the last calamity in this area. Based on the results, it can be assumed that in the next outbreak of gypsy moth populations, azygospores will infect gypsy moth larvae under favourable environmental conditions.

It would be desirable to conduct the monitoring of dispersion and mapping of E. maimaiga in the territory of the Republic of Serbia to estimate its total share in the prevention of gypsy moth outbreaks and to develop valid forest management 
plans aimed at timely implementation of appropriate protection measures, in line with the current Forestry Development Strategy of Serbia.

\section{REFERENCES}

Belme, M.D. (1995): Gypsy moths (Lymantria dispar) in the Niagara Region: population density variation, introduction of an entomopathogenic fungus (Entomophaga maimaiga) and occurrence of nuclear polyhedrosis virus. Master thesis, Brock University St. Catharines, Ontario

Hajek, A.E. (1999): Pathology and Epizootiology of Entomophaga maimaiga Infections in Forest Lepidoptera. Microbiology and Molecular Biology Reviews, 63(4): 814-835.

Најек, A.E., Bauer, L., McManus, M.L., Wheeler M.M. (1998): Distribution of resting spores of the Lymantria dispar pathogen Entomophaga maimaiga in soil and on bark. BioControl, 43: 189-200.

Hajek, A.E., Carruthers, R.I., Soper, R.S. (1990): Temperature and Moisture Relations of Sporulation and Germination by Entomophaga maimaiga (Zygomycetes: Entomophthoraceae), a Fungal Pathogen of Lymantria dispar (Lepidoptera: Lymantriidae). Environmental Entomology, 19(1): 85-90.

Hajek, A.E., Shimazu, M., Knoblauch, B. (2000): Isolating a species of Entomophthorales using resting spore-bearing soil. Journal of Invertebrate Pathology, 75: 298-300.

Hajek, A.E., Wheeler, M. (2004): Using bioassays to estimate abundance of Entomophaga maimaiga resting spores in soil. Journal of Invertebrate Pathology, 86: 61-64.

Pilarska, D., McManusm M., Hajek A.E., Herard, F. (2000): Introduction of the entomopathogenic fungus Entomophaga maimaiga to a Lymantria dispar population in Bulgaria. Anzeiger für Schädlingskunde, 73(5): 125-126.

Speare, A.T., Colley, R.H. (1912): The artificial use of the brown-tail fungus in Massachusetts with practical suggestions for private experiments, and a brief note on a fungous disease of the gypsy caterpillar. Wright \& Potter, Boston, Mass.

Stojanović, D., Kresoja, M., Drekić, M., Poljaković-Pajnik, L., Krklec-Jerinkić, N., Orlović, S. (2016): Predviđanje prenamnoženja gubara (Lymantria dispar) u svetlu klimatskih promena. Topola, 198(197-198): 15-24.

Tabaković-Tošić, M., (2014a): Distribution of Entomophaga maimaiga in Central part of Serbia in the period 2011-2013. Silva Balcanica, 15(1): 110-115.

Tabaković-Tošić, M. (2014b): Suppression of gypsy moth population in mountain avala (Republic of Serbia) by introduction of entomopathogenic fungus Entomophaga maimaiga. Comptes rendus de l'Académie bulgare des sciences: sciences mathématiques et naturelles, 67(1): 61-66.

Tabaković-Tošić, M., (2015): Entomopathogenic fungus Entomophaga maimaiga and integrated pest management in Serbia. Communications in Agricultural Applied Biological Sciences, 80(2): 153-159. 
Tabaković-Tošić, M., Georgiev, G., Mirchev, P., Tošić, D., Golubović-Ćurguz, V. (2012): Entomophaga maimaiga - New entomopathogenic fungus in the Republic of Serbia. African Journal of Biotechnology, Vol. 11(34): 8571-8577.

Walsh, S.R.A., Tyrrell, D., Humber, R.A., Silver, J.C. (1990): DNA restriction fragment length polymorphisms in the rDNA repeat unit of Entomophaga. Experimental Mycology, 14(4): 381-392.

Weseloh, R.M., Andreadis, T.G. (1992): Mechanisms of Transmission of the Gypsy Moth (Lepidoptera: Lymantriidae) Fungus, Entomophaga maimaiga (Entomophthorales: Entomophthoraceae) and Effects of Site Conditions on Its Prevalence. Environmental Entomology, 21(4): 901-906.

\title{
TESTING OF SOIL DISTRIBUTION, VIABILITY, AND INFECTIVITY OF AZYGOSPORES OF THE ENTOMOPATHOGENIC FUNGUS Entomophaga maimaiga
}

\author{
Mara TABAKOVIĆ-TOŠIĆ, Sanja JOVANOVIĆ, Marija MILOSAVLJEVIĆ
}

\section{Summary}

Entomophaga maimaiga is one of the best-known gypsy moth pathogens with increasing importance in the biological control aimed at reducing the population of this defoliator. The territory of the Republic of Serbia is a very favorable gypsy moth habitat, and the problems caused by its larvae during the periods of outbreaks are so great that they can lead to forest defoliation and forest health deterioration.

In the Republic of Serbia, E. maimaiga was first recorded in 2011 (as a new species in the microflora of Serbia) during the gypsy moth outbreak (2009-2014), which was the last to date. In 2011, numerous dead caterpillars were found on and around trees in oak and beech stands of the Belgrade and Valjevo regions in Serbia. Subsequent laboratory analyses revealed that they contained azygospores and conidia of this fungus. The assisted introduction of E. maimaiga was carried out in Compartments 28 and 30 of the FMU Avala on Mt. Avala in 2011. It led to an epizootic in the following year and stopped the outbreak of the gypsy moth in the area.

Since it has been seven years since the outbreak, we tested the viability and infectivity of E. maimaiga azygospores obtained from the soil samples from Avala Mountain where its assisted introduction was carried out. We used larvae from the laboratory gypsy moth population and applied the bioassay method. The results show that azygospores are present in the given soil samples, they are viable and their infectivity is conserved. It can be concluded that in the case of an outbreak of gypsy moth populations in the future, they will exhibit their entomopathogenic effect. 


\title{
ISPITIVANJE PRISUSTVA U ZEMLJIŠTU, VIJABILNOSTI I INFEKTIVNOG POTENCIJALA AZIGOSPORA ENTOMOPATOGENE GLJIVE Entomophaga maimaiga
}

\author{
Mara TABAKOVIĆ-TOŠIĆ, Sanja JOVANOVIĆ, Marija MILOSAVLJEVIĆ
}

\section{Rezime}

Entomophaga maimaiga je jedan od najpoznatijih patogena gubara i zauzima sve veći značaj u biološkim merama borbe, koje imaju za cilj smanjenje brojnosti populacija ovog defolijatora. Teritorija Republike Srbije je veoma povoljno stanište za gubara, te su $i$ problemi koje njegove larve izazivaju u periodima gradacije veliki, dovodeći do golobrsta $i$ slabljenja zdravstvenog stanja šuma.

U Republici Srbiji E. maimaiga je prvi put uočena 2011. godine (nova vrsta $u$ mikoflori Srbije), kada je bila u toku gradacija gubara (2009-2014), poslednja do danas. U Srbiji, u hrastovim $i$ bukovim sastojinama u regionu Beograda $i$ Valjeva, 2011. godine nađene su brojne mrtve gusenice gubara na stablima i oko njh, za koje se kasnije, laboratorijskim analizama, utvrdilo da sadrže azigospore $i$ konidije ove gljive. Potpomognuta introdukcija E. maimaiga vršena je 2011. godine na planini Avala, u Gazdinskoj jedinici Avala, odeljenjima 28 i 30, i već naredne je uzrokovala epizootiju, te dovela do sloma gradacije gubara na tom prostoru.

$S$ obzirom da je od tada prošlo 7 godina, metodom bioeseja ispitivali smo vijabilnost i infektivni potencijal azigospora E. maimaiga iz uzoraka zemljišta sa planine Avala, gde je vršena njena potpomognuta introdukcija, na larvama iz laboratorijske populacije gubara. Rezultati su pokazali da su azigospore prisutne u datim uzorcima zemljišta, kao $i$ da su vijabilne $i$ da je njihov infektivni potencijal očuvan, te se može zaključiti da će u slučaju naredne gradacije populacija gubara, one ispoljiti entomopatogeni efekat. 